ISSN: 2302-8556

E-Jurnal Akuntansi Universitas Udayana

Vol.25.3.Desember (2018): 2430- 2455

DOI: https://doi.org/10.24843/EJA.2018.v25.i03.p30

\title{
Reaksi Pasar Terhadap Pengumuman Pergantian CEO di Bursa Efek Indonesia
}

\author{
I Kadek Diky Agusnawan ${ }^{1}$ \\ Dewa Gede Wirama ${ }^{2}$
}

\author{
${ }^{1}$ Fakultas Ekonomi dan Bisnis Universitas Udayana (Unud), Bali, Indonesia \\ email: dikyagus.da@gmail.com / Tlp: 08781083243 \\ ${ }^{2}$ Fakultas Ekonomi dan Bisnis Universitas Udayana (Unud), Bali, Indonesia
}

\begin{abstract}
ABSTRAK
Pengumuman pergantian CEO mengindikasikan suatu perubahan dalam manajemen perusahaan demi meningkatkan kinerja perusahaan. Tujuan dari penelitian ini adalah menguji apakah pasar modal mereaksi pengumuman pergantian CEO. Penelitian ini menggunakan metode event study dan sampel dipilih secara purposive. Sampel penelitian terdiri 79 perusahaan yang terdaftar di BEI. Berdasarkan hasil analisis ditemukan bahwa tidak terdapat abnormal return di sekitar pengumuman pergantian CEO. Hasil penelitian menunjukkan bahwa tidak ada kandungan informasi pada pengumuman pergantian CEO. Hasil penelitian ini konsisten dengan penelitian Warner et al., (1998) dan Setiawan (2008). Hasil penelitian tidak konsisten dengan penelitian Weisbach (1988), Kang dan Shivdasani (1996), Derment-Ferere dan Renneboog (2000), Bahtera (2017).
\end{abstract}

Kata kunci: Chief executive officer, cumulative abnormal return, reaksi pasar

\begin{abstract}
Announcement of CEO turnover indicates a change in company management in order to improve company performance. The purpose of this study is to test whether the capital market reacts to CEO turnover announcements. This study uses event study method and the sample was selected purposively. The research sample consisted of 79 companies listed in the IDX. Based on the results of the analysis it is found that there are no abnormal returns around the CEO turnover announcement. The results shows that there is no information content in the CEO turnover announcement. The results of this study is consistent with the research of Warner et al., (1998) and Setiawan (2008). The results of the study is not consistent with the research of Weisbach (1988), Kang and Shivdasani (1996), Derment-Ferere and Renneboog (2000), Bahtera (2017).

Keywords: Chief executive officer, cumulative abnormal return, market reaction
\end{abstract}

\section{PENDAHULUAN}

Bagi investor melihat informasi mengenai kinerja perusahaan, baik dan buruk kinerja perusahaan dapat dilihat dari kerja keras manajemen puncak dalam mengelola perusahaan secara langsung dari menentukan tujuan perusahaan, perencanaan, pengorganisasian dan pengawasan. Menurut UU No. 40 Tahun 2007 menyatakan bahwa chief executive officer (CEO) atau disebut juga direktur utama 
atau presiden direktur adalah orang yang menduduki kepemimpinan tertinggi di suatu perusahaan. CEO memiliki wewenang dan tanggung jawab penuh dalam pengurusan dan penentuan kebijakan yang sesuai dengan kepentingan, maksud dan tujuan perusahaan.

Pengumuman pergantian CEO mengindikasikan suatu perubahan dalam pengelolaan manajemen perusahaan dengan menerapkan kebijakan dan peraturan, serta prosedur manajemen yang baru demi meningkatkan kinerja perusahaan. Pengangkatan, pemberhentian dan pergantian CEO ditetapkan melalui rapat umum pemegang saham (RUPS) dan dipublikasikan di media publik sebagai tanggung jawab keterbukaan informasi oleh perusahaan. Menurut Neumann dan Voetman (1999) kinerja perusahaan yang memburuk meningkatkan kemungkinan terjadinya pergantian CEO. Terjadinya pergantian ini diharapkan dapat meningkatkan kinerja perusahaan lebih baik di bawah kepemimpinan baru dengan kebijakan dan strategi baru yang ditetapkan oleh CEO baru. Perusahaan melakukan pergantian CEO untuk menyeimbangkan roda kehidupan dan meningkatkan kinerja perusahaan. Pergantian CEO dilakukan oleh perusahaan secara rutin dan non-rutin. Pergantian CEO rutin dapat dilihat pada struktur perusahaan, dilakukan secara teratur dan merupakan proses pergantian yang telah direncanakan. Sedangkan, Pergantian CEO non-rutin diklasifikasikan sebagai berikut. Pertama, CEO dipecat, dipaksa keluar dari posisinya, karena perbedaan kebijakan yang tidak spesifik. Kedua, CEO pensiun berusia kurang dari 60 tahun dan tidak ada pengumuman bahwa CEO tersebut meninggal, meninggalkan perusahaan karena kesehatan yang buruk, atau menerima posisi lain. Ketiga, CEO 
I Kadek Diky Agusnawan dan Dewa Gede Wirama. Reaksi...

"pensiun" tapi meninggalkan pekerjaan dalam waktu enam bulan dari pengumuman "pensiun". Keempat, CEO tetap bekerja sebagai anggota dewan komisaris, penelitian ini akan mengklasifikasikan sebagai pergantian CEO sukarela.

Fenomena pergantian chief executive officer (CEO) adalah fenomena mikro yang terjadi pada internal perusahaan. Pergantian ini mengindikasikan adanya penurunan kinerja perusahaan yang dialami perusahaan akibat kebijakan yang diambil oleh manajemen, sehingga perusahaan bertindak tegas terhadap hal yang terjadi. Seperti kasus PT Wijaya Karya Tbk mengalami beberapa insiden seperti: kecelakaan kerja proyek Tol Manado-Bitung di Desa Tumalungun, Minahasa Utara, kecelakaan kerja di proyek Tol Trans Sumatera dan Besi hollow jatu dari proyek rumah susun, Setiabudi, Jakarta (www.merdeka.com). Memperbaiki kinerja perusahaan, maka perusahaan memperbaharui komposisi direksi dengan harapan mempercepat proyek yang ditangani oleh PT Wijaya Karya Tbk. Menurut Yuliana (2011) apabila kinerja dari CEO tersebut dianggap baik maka saat RUPS para pemegang saham memutuskan untuk memperpanjang masa jabatan CEO, namun apabila pemegang saham merasa kinerja dari CEO tersebut kurang baik, maka pemegang saham dapat memecat CEO melalui RUPS tahunan.

Motivasi penelitian ini adalah topik pergantian CEO merupakan topik yang menarik dan dengan topik ini ingin mengetahui apakah terdapat kandungan informasi terhadap pengumuman pergantian CEO. Hal ini dikarenakan bahwa pergantian CEO merupakan salah satu siklus diperusahaan yang penting bagi kinerja perusahaan. Menurut Jayanthi dan Putra (2013) tidak jarang suatu 
perusahaan melakukan pergantian CEO, dengan alasan dapat dijadikan salah satu strategi bagi perusahaan yang sedang mengalami penurunan dan membangkitkan citranya perusahaan. Hal ini dikaitkan dengan kinerja sebelumnya dan harapan bagi investor dalam meramal prospek kinerja dimasa depan. Reaksi pasar digambarkan dengan naik-turunnya harga saham yang terjadi disekitar tanggal pengumuman pergantian CEO. Ada berbagai cara pengukuran reaksi pasar terhadap suatu pengumuman yang dipublikasikan, diantaranya adalah: abnormal return, security return variance, dan trading volume activity. Abnormal return adalah selisih antara return pasar dengan return saham.

Berbagai penelitian yang telah dilakukan di luar negeri memberikan hasil yang tidak konsisten. Penelitian yang dilakukan di United States yang dilakukan oleh Warner et al., (1988) menyatakan bahwa tidak terdapat reaksi harga saham pada pengumuman pergantian CEO. Disebabkan oleh terjadi kinerja yang negatif signifikan terjadi pada bulan berikutnya. Sedangkan, penelitian Weisbach (1988) yang menunjukkan adanya abnormal return positif signifikan pada saat pengumuman pergantian top management tahun 1977-1980. Hasil penelitian di Jepang yang dilakukan oleh Kang dan Shivdasani (1996) menunjukkan adanya return yang signifikan positif pada saat pengumuman pergantian top management. Penelitian yang dilakukan oleh Derment-Ferere dan Renneboog (2000) di Perancis menunjukkan adanya abnormal return positif yang signifikan atas pengunduran diri CEO. Bahtera (2017) bahwa pergantian dari dalam (inside) berpengaruh positif, sedangkan pergantian dari luar (outside) berpengaruh negatif. Hasil penelitian Primasari et al., (2016) menyatakan tidak ada reaksi pasar pada 
pergantian CEO baik perempuan maupun laki-laki. Berdasarkan hasil penelitian Warner et al., (1988), Weisbach (1988), Kang dan Shivdasani (1996), dan Derment-Ferere dan Renneboog (2000) mengindikasikan bahwa pergantian CEO berhubungan dengan kinerja perusahaan.

Penelitian ini akan mencoba meneliti reaksi pasar terhadap pengumuman pergantian chief executive officer (CEO) perusahaan. Pergantian CEO secara normal dengan alasan yang tidak mengganggu kinerja perusahaan yaitu meninggal, pensiun, dan masa jabatan habis tidak dimasukkan kedalam penelitian. Pernyataan ini didukung oleh Friedman and Singh (1989) menyatakan bahwa pengunduran diri secara teratur atau sudah direncanakan tidak berhubungan dengan kinerja, karena kondisi organisasi masih inheren dan stabil. Penelitian ini menggunakan metode event study. Reaksi ini dapat diukur dengan mengukur menggunakan return sebagai nilai perubahan harga atau menggunakan abnormal return (Dewi et al., 2017). Harga saham tercermin dalam abnormal return yang merupakan perbedaan antara tingkat keuntungan sebenarnya dengan keuntungan yang diekspetasikan oleh investor. Penelitian ini menggunakan metode cumulative abnormal return (CAR) dengan market-adjusted model tujuan mengukur reaksi pasar terhadap pengumuman pergantian CEO. Tindakan nyata apabila investor beranggapan suatu informasi itu bernilai adalah dilihat dari aktivitas jual beli saham sekuritas. Peneliti ingin mengetahui reaksi pasar melalui tindakan para investor dalam merespon informasi publik tentang pengumuman pergantian CEO yang dapat diukur dengan menggunakan abnormal return. 
Berdasarkan masalah yang dapat dirumuskan yaitu apakah peristiwa pengumuman pergantian chief executive officer (CEO) direaksi oleh pasar modal?. Tujuan penelitian ini adalah membuktikan secara empiris peristiwa pengumuman pergantian chief executive officer (CEO) direaksi oleh pasar modal. Penelitian ini dapat memberikan manfaat teoritis yang diharapkan dapat memberikan pengetahuan dan informasi mengenai kandungan informasi yang terdapat pada fenomena pergantian CEO. Penelitian ini diharapkan memberikan informasi bagi investor untuk mempertimbangkan peristiwa pergantian chief executive officer (CEO) dalam pengambilan keputusan dan bagi pihak manajemen agar mempublikasikan pengumuman pergantian chief executive officer (CEO) lebih terbuka melalui media massa yang terpercaya.

Efisiensi pasar modal mencerminkan reaksi terhadap seluruh informasi yang tersedia untuk membentuk harga ekuilibrium baru. Harga ekuilibrium suatu aktiva di dalam pasar kompetitif ditentukan oleh penawaran dan permintaan agregat. Efisiensi dapat ditinjau dari segi ketersediaan informasi ataupun dari kecanggihan investor dalam pengambilan keputusan berdasarkan analisis dari informasi yang ada. Efisiensi pasar yang ditinjau pada sudut pandang informasi disebut dengan efisiensi pasar secara informasi, sedangkan efisiensi pasar ditinjau dari kecanggihan investor untuk mengambila keputusan berdasarkan analisis. Kunci utama untuk mengukur pasar efisien adalah mengukur hubungan antara harga sekuritas dengan informasi (Hartono, 2016:606). Fama dalam Hartono (2016:606) menyatakan terdapat tiga macam bentuk utama dari efisiensi pasar berdasarkan ketiga macam bentuk dari informasi, yaitu efisiensi pasar lemah (weak form) pasar 
I Kadek Diky Agusnawan dan Dewa Gede Wirama. Reaksi...

dikatakan efisien dalam bentuk lemah jika harga-harga dari sekuritas mencerminkan secara penuh informasi masa lalu. Efisien setengah kuat (semistrong effect) jika harga-harga sekuritas secara penuh mencerminkan semua informasi yang dipublikasikan (all publicy available information) termasuk informasi yang berada di laporan-laporan keuangan emiten. Efisiensi pasar kuat (strong form) jika harga-harga sekuritas secara penuh mencerminkan seluruh informasi yang dipublikasikan dan informasi yang bersifat pribadi.

Studi peristiwa merupakan studi yang mempelajari reaksi pasar tehadap peristiwa yang informasinya dipublikasikan sebagai suatu pengumuman. Studi peristiwa yang digunakan untuk menguji kandungan informasi dai suatu pengumuman dan dapat juga digunakan untuk menguji efisiensi pasar bentuk setengah kuat (Hartono, 2016:643). Reaksi pasar menunjukkan dengan adanya perubahan harga dari sekuritas yang bersangkutan.

Menurut Alwi (2003:89) ada beberapa faktor yang mempengaruhi pergerakan saham atau indeks harga saham, antara lain fenomena internal (lingkungan mikro) seperti, pengumuman tentang pemasaran, produksi, penjualan seperti pengiklanan, laporan produksi, laporan keamanan produk dan laporan penjualan. pengumuman badan direksi manajemen, pengumuman pengambilalihan diversifikasi, pengumuman ketenagakerjaan seperti negosiasi baru, kontrak baru, pemogokan dan lainnya, pengumuman laporan keuangan perusahaan, seperti peramalan laba sebelum akhir tahun fiskal dan setelah akhir tahun fiskal, EPS, DPS, PER, NPM, ROA, dan lain-lain. 
ISSN: 2302-8556

E-Jurnal Akuntansi Universitas Udayana

Vol.25.3.Desember (2018): 2427- 2455

Fenomena eksternal (lingkungan makro) pengumuman dari pemerintah, pengumuman hukum (legal announcements). Pengumuman industri sekuritas (securities announcements) seperti laporan pertemuan tahunan, insider. Gejolak politik dalam negeri dan fluktuasi nilai tukar juga merupakan faktor yang berpengaruh signifikan pada terjadinya pergerakan harga saham di Bursa Efek Indonesia suatu negara.

Menurut Nainggolan (2009) pasar yang bereaksi menunjukkan bahwa terdapat suatu kandungan informasi pada pengumuman tersebut. Pengumuman yang mengandung informasi akan menunjukkan reaksi yang terlihat pada perubahan harga dan volume perdagangan. Beaver (1968) mendefinisikan informasi sebagai perubahan ekspektasi yang timbul dari suatu peristiwa. Suatu pengumuman dikatakan mempunyai kandungan informasi bila menyebabkan perubahan penilaian investor tentang probabilitas distribusi return masa depan dari suatu sekuritas. Perubahan perilaku dapat terjadi dengan pembelian atau penjualan saham di atas normal dan penurunan atau kenaikan volume jual-beli.

CEO adalah bagian dari manajemen puncak yang memiliki peranan penting dalam penentuan strategis perusahaan dan kebijakan akuntansi. Mereka mempunyai wewenang dan tanggungjawab penuh atas kepengurusan perusahaan. Kekuasaan dan kewenangan mereka diawasi oleh Dewan Komisaris. Dewan Komisaris bertugas untuk melakukan pengawasan secara keseluruhan dan/atau khusus sesuai dengan anggaran dasar, serta menjadi penasihat bagi direksi. Namun, kekuasaan tertinggi tetap pada rapat umum pemegang saham (RUPS). Segala sesuatu yang berhubungan dengan perubahan anggaran dasar perusahaan, 
termasuk perubahan dalam kepengurusan perusahaan harus diputuskan melalui RUPS.

CEO adalah wiraswatawan (menetapkan tujuan), perencana strategis (merencanakan), pembentuk organisasi (mengorganisir), pemimpin (memberikan arahan), dan pengendali utama (kontrol). CEO harus secara bersamaan menangani berbagai kegiatan yang berbeda-beda dalam rencana pekerjaan dan sedikit waktu yang memungkinkannya untuk mempertimbangkan. Mintzberg dalam Jauch dan Glueck (1989) memecah menjadi beberapa peranan CEO yang merupakan bentuk kegiatan yang berbeda-beda yang dapat dilakukan oleh seorang CEO. Beberapa CEO menurut Mintzberg yaitu pertama, peranan interpersonal, sebagai simbol organisasi, seorang Dirut (CEO) melaksanakan sejumlah tugas rutin yang bersifat resmi dan sosial untuk memperkenalkan perusahaan kepada orang luar. Sebagai seorang pemimpin (leader) CEO mempunyai tanggung jawab untuk menetapkan staf organisasi serta melatih dan memotivasi bawahannya. Peranannya sebagai penghubung (liaison) manajer menjaga jaringan hubungan eksternal demi mendapatkan peluang dan informasi. Kedua, peranan informasional, dalam memainkan perannya sebagai pemantau (monitor), manajer membaca laporan, mengikuti pertemuan untuk mencari informasi mengenai organisasi dan lingkungannya. Sebagai informan terpercaya, CEO meneruskan banyak informasi yang diterima kepada orang luar dan dalam. Informasi tentang organisasi juga diteruskan kepada orang lain melalui via email, via telepon atau rapat dengan dewan karena manajer bertindak sebagai juru bicara dari organisasinya. Ketiga, peranan pengambil keputusan, sebagai wiraswasta, CEO melakukan tugas 
strategis untuk memutuskan proyek yang diambil untuk mengambil keuntungan bagi perusahaan.

CEO mengadakan pertemuan strategis dan peninjauan untuk melaksanakan hal ini dan untuk membereskan masalah serta menyelesaikan krisis. Akhirnya, manajer puncak bertanggung jawab untuk mewakili perusahaan sebagai negotiator untuk kontrak dengan penyalur besar dan pelanggan besar. Berdasarkan fungsi dan peranan CEO dalam menjalankan perusahaan di atas, kinerja perusahaan sangatlah juga ditentukan oleh kinerja CEO. Menurut Denis dan Denis (1995), terakadang pergantian CEO dihubungkan dengan tingkat kinerja perusahaan yang buruk, sehingga keputusan oleh perusahaan untuk melakukan pergantian manajemen perusahaan dapat dilakukan demi memperbaiki kinerja perusahaan.

Menurut Undang-Undang No. 40 Tahun 2007 Pasal 94 Ayat 1 tentang perseroan terbatas menyatakan direksi diangkat oleh rapat umum pemegang saham (RUPS). Pergantian kepemimpinan eksekutif suatu perusahaan adalah peristiwa yang berpengaruh bagi kelangsungan hidup perusahaan. Kemampuan, pilihan, dan keputusan penting CEO berdampak pada pilihan proyek, kebijakan finansial, dan kultur perusahaan. Keputusan yang berbeda dari tiap individu, dalam pergantian CEO dapat mengubah masa depan dan kinerja perusahaan (Clayton et al., 2003). Proses pergantian rutin adalah pergantian yang dilakukan secara teratur, dan merupakan proses pergantian yang sudah direncanakan (Vancil dalam Pourciau, 1993). Pergantian rutin terjadi karena CEO lama habis masa 
jabatan. Setelah pergantian, CEO dapat tetap menduduki jabatan sebagai Dewan Komisaris dan tetap mengawasi jalannya perusahaan.

Pergantian non-rutin adalah pergantian yang dilakukan tanpa perencanaan dan tidak teratur. Pergantian secara nonrutin dapat dilihat dari susunan Dewan Komisaris yang baru. Apabila CEO lama tidak tercantum dalam susunan Dewan Komisaris yang baru maka dapat dikategorikan pergantian nonrutin (Kang dan Shivdasani, 1996). Clayton et al., (2003) dalam penelitiannya mengklasifikasikan pergantian secara sukarela (pengunduran diri) atau pergantian yang dipaksakan. Pergantian yang dipaksakan dapat disebabkan karena CEO dipecat, usia di atas 60 tahun, alasan kesehatan yang sudah tidak memungkinkan, atau keluar/ pindah ke perusahaan lain (Clayton et al., 2003). Menurut Neumann dan Voetman (1999) indikasi pergantian dipaksakan diklasifikasikan menjadi tiga yaitu CEO lama pergi dan tidak memegang jabatan apa-apa lagi, pergantian dilakukan dengan perjanjian yang menguntungkan antara CEO lama dan dewan direksi, atau dilakukannnya perubahan organisasi (merger misalnya). Menurut Warner et al., (1988) mengindikasikan pergantian top management dengan tiga alasan terbesar yaitu pengunduran diri, mengambil posisi lain pada perusahaan, dan sakit atau meninggal dunia, sedangkan sisanya adalah penurunan kinerja, mempunyai ketertarikan lain/ mengambil posisi di luar perusahaan, kebijakan tak sesuai, dan dipecat. Dahya dan McConnell (2002) mengklasifikasikan pergantian yang dipaksa ke dalam tiga bagian yaitu dipecat, berhenti dan kinerja CEO lama yang buruk. 
ISSN: 2302-8556

E-Jurnal Akuntansi Universitas Udayana Vol.25.3.Desember (2018): 2427- 2455

Studi peristiwa menganalisis return tak normal dari sekuritas yang mungkin terjadi di sekitar pengumuman dari suatu peristiwa. Perubahan harga tersebut akan menyebabkan adanya abnormal return (Hartono, 2016:667). Abnormal return adalah selisih antara return sesungguhnya yang terjadi dengan return ekspetasian.

Return realisasian atau return sesungguhnya merupakan return yang terjadi pada waktu ke-t yang merupakan selisih harga sekarang relatif terhadap harga sebelumnya atau dapat dihitung dengan rumus $\left(\mathrm{P}_{\mathrm{i}, \mathrm{t}}-\mathrm{P}_{\mathrm{i}, \mathrm{t}-1}\right) / \mathrm{P}_{\mathrm{i}, \mathrm{t}-1}$. Sedangkan, untuk mendapatkan expected return. Untuk mengestimasi expected return dengan menggunakan 3 (tiga) model estimasi, yaitu; mean-adjusted model, market model, dan market-adjusted model (Hartono, 2016:667).

Weisbach (1988) menguji hubungan antara pengawasan kinerja CEO oleh inside dan outside directors dengan pergantian CEO. Pergantian CEO diukur menggunakan return saham dan perubahan earnings kinerja utama. Penelitian ini menggunakan sampel 495 perusahaan terdapat di NYSE periode 1977-1980. Hasil penelitian tidak menunjukkan reaksi yang signifikan. Kang dan Shivdasani (1996) melakukan penelitian di Jepang, dengan sampel 432 perusahaan pada periode 1985-1990. Penelitian ini menemukan abnormal return positif terhadap pergantian CEO. Jepang selama proses pergantian CEO ditemukan mekanisme pendisipinan sehingga memberikan efek yang baik terhadap maksimalisasi kekayaan atau keuntungan pemegang saham terutama pergantian CEO dengan top manager yang berasal dari luar perusahaan. Penelitian di Perancis dilakukan oleh Dherment-Ferere dan Renneboog (2000) dengan sampel 207 perusahaan yang listing perode 1988-1992 dengan 277 pergantian CEO. Penelitian ini menguji 
reaksi harga saham atas perubahan dalam top management. Perbedaan hasil terjadi berdasarkan tipe pergantian CEO, yaitu pergantian yang disebabkan pemecatan, pengunduran diri, secara sukarela dan berdasarkan pertimbangan usia. Pengumuman pergantian CEO menunjukkan abnormal return sebesar 0,5\% terhadap pergantian CEO yang disebabkan oleh pemecatan. Klasifikasi lebih detail dalam pergantian top management berdasakan asal, ukuran perusahaan dan tingkat diversifikasi perusahaan.

Nainggolan (2009) melakukan penelitian tentang reaksi pasar terhadap pengumuman pergantian CEO dengan abnormal volume dengan sampel 120 pengumuman tanpa memperhatikan pengumuman lain (confounding effect) dan 74 pengumuman memperhatikan pengumuman lain (confounding effect). Hasil penelitian ini menunjukkan bahwa pasar bereaksi terhadap pengumuman pergantian CEO. Hasil penelitian Bahtera (2017) melakukan analisis pengumuman pergantian chief executive officer (CEO) dengan sampel 55 pengumuman. Hasil dari penelitiannya adalah pergantian dari dalam (inside) berpengaruh positif dengan persepsi akan meneruskan gaya kepemimpinan dari pendahulu, sedangkan pergantian dari luar (outside) berpengaruh negatif karena ketidakpastian kepemimpinan oleh orang baru sehingga menjadi kabar buruk bagi investor.

Pergantian CEO dilaksanakan oleh perusahaan pada saat keadaan perusahaan yang tidak stabil dan menurun, sehingga perusahaan mengambil kebijakan mengganti CEO agar kinerja perusahaan membaik dan mendapatkan kepercayaan oleh investor. Berdasarkan hasil penelitian dari beberapa peneliti 
yang menyatakan pergantian CEO memiliki dampak positif bagi perusahaan dan pasar bereaksi terhadap hal ini. Maka hipotesis penelitian dapat dinyatakan sebagai berikut.

$\mathrm{H}_{1 \text { : }}$ Pengumuman pergantian chief executive officer (CEO) direaksi positif pasar modal.

\section{METODE PENELITIAN}

Metode Penelitian yang digunakan adalah studi peristiwa (event study). Studi peristiwa (event study) merupakan studi yang mempelajari reaksi pasar terhadap suatu peristiwa yang diinformasinya dipublikasikan sebagai suatu pengumuman (Hartono, 2016:643). Bertujuan menguji kandungan informasi dari suatu pengumuman terhadap suatu peristiwa. Peristiwa yang diuji adalah pada saat adanya pengumuman pergantian chief executive officer (CEO) dengan menggunakan jendela peristiwa selama 5 hari. Penggunaan jendela peristiwa selama 5 hari bertujuan menghindari bias atas peristiwa (corporate action) yang mungkin terjadi selama periode pengamatan. Informasi dari pengumuman pergantian chief executive officer (CEO) akan diuji terhadap reaksi investor dalam pasar modal yang diproksikan dengan cumulative abnormal return.

Penelitian ini mneggunakan data sekunder, yaitu data yang diperoleh dengan mengakses finance.yahoo.com. Lokasi penelitian ini pada Bursa Efek Indonesia (BEI) karena menyediakan data perusahaan go public dan informasi harga saham harian selama periode pengamatan yang diperoleh dengan mengakses situs resmi www.idx.co.id, dan www.finance.yahoo.com. Objek dari penelitian ini adalah reaksi investor dalam pasar modal dari pengumuman 
pergantian chief executive officer (CEO) pada tanggal rapat umum pemegang saham (RUPS) atau rapat umum pemegang saham luar biasa (RUPSLB). Reaksi pasar diukur dengan menggunakan cumulative abnormal return (CAR).

Variabel independen dalam penelitian ini adalah pengumuman pergantian chief executive officer (CEO) oleh media diumumkannya pergantian CEO pada rapat umum pemegang saham (RUPS) atau rapat umum pemegang saham luar biasa (RUPSLB). Variabel dependen dalam penelitian ini adalah reaksi pasar modal yang diprosikan dengan cumulative abnormal return (CAR).

Penelitian ini menggunakan perhitungan abnormal return yaitu marketadjusted model. Market-adjusted model (model sesuaian-pasar) mengganggap bahwa penduga yang terbaik untuk mengestimasi return suatu sekuritas adalah return indeks pasar pada saat tersebut ( Hartono, 2016: 679). Hal ini dikarenakan, pasar modal di Indonesia adalah pasar modal dalam tahap sedang berkembang, dimana pada tahap tersebut pasar modal mempunyai ciri yaitu sebagian besar saham yang diperdagangkan transaksinya tidak likuid sehingga saham tersebut jarang diperjual-belikan, akibatnya banyak saham yang menghasilkan return nol selama tidak terjadi transaksi (Kurniasari dan Nugraheni, 2003). Sedianingtias (2010), mengatakan bahwa dengan menggunakan market-adjusted model, maka tidak perlu menggunakan periode estimasi untuk membentuk model. Langkahlangkah untuk menghitung abnormal return, sebagai berikut:

Return realisasian atau return sesungguhnya adalah return yang terjadi pada waktu ke-t merupakan selisih antara harga sekuritas hari sekarang relatif terhadap harga kemarin. Dapat dihitung dengan rumus sebagai berikut: 


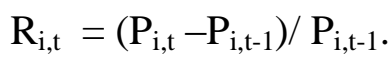

Sumber: Hartono (2015: 265)

Keterangan:

$\mathrm{R}_{\text {it }}$ : return individual saham i pada saat $\mathrm{t}$

$\mathrm{P}_{\mathrm{t}}$ : harga penutupan saham i pada saat $\mathrm{t}$

$\mathrm{P}_{\mathrm{t}-1}$ : harga penutupan saham i pada saat $\mathrm{t}-1$

Return ekspetasian merupakan return yang diestimasi (Hartono, 2015:648). Estimasi return ekspetasian dalam penelitian ini menggunakan harga index IHSG pada hari sekarang relatif terhadap harga kemarin. Dapat dihitung dengan rumus sebagai berikut:

$$
\mathrm{Rm}, \mathrm{t}=\frac{\mathrm{IHSGt}-\mathrm{IHSGt}-1}{\text { IHSGt-1 }}
$$

Sumber: Hartono (2015: 569)

Keterangan:

$\mathrm{Rm}_{\mathrm{t}} \quad$ : tingkat return pasar pada saat $\mathrm{t}$

$\mathrm{IHSG}_{\mathrm{t}} \quad$ : Indeks Harga Saham Gabungan pada saat $\mathrm{t}$

$\mathrm{IHSG}_{\mathrm{t}-1} \quad$ : Indeks Harga Saham Gabungan pada saat t- 1

Abnormal return adalah selisih antara return sesungguhnya dengan return ekspetasian yang dirumuskan menggunakan market-adjusted abnormal return sebagai berikut:

$$
A R_{i, t}=R_{i, t}-R_{m, t}
$$

Sumber: Hartono (2015:648)

Keterangan:

$\mathrm{AR}_{\mathrm{t}} \quad$ : abnormal return saham i saat $\mathrm{t}$

$\mathrm{R}_{\mathrm{it}} \quad$ : return individual saham i saat $\mathrm{t}$

$\mathrm{Rm}_{\mathrm{t}} \quad$ : tingkat return pasar saham saat $\mathrm{t}$

Cumulative abnormal return adalah penjumlahan abnormal return suatu perusahaan selama periode amatan. Abnormal return terjadi ketika investor 
bereaksi terhadap suatu informasi atau perisrtiwa, akibat kenaikan atau penurunan harga saham. CAR dihitung dengan rumus sebagai berikut:

$$
C A R=\sum A R_{i_{2} t}
$$

Pergantian chief executive officer (CEO) merupakan kebijakan perusahaan untuk memperbaiki kinerja perusahaan. Menurut Badriyah (2015) pergantian CEO merupakan suatu sinyal dari perusahaan akan melakukan suatu perubahan dalam mengelola perusahaan dan hasil penelitian menyatakan berpengaruh positif terhadap kinerja perusahaan. Pergantian CEO pada klasifikasi tertentu tidak dimasukan kedalam penelitian, yaitu; 1) meninggal; 2) pensiun; 3) masa jabatan habis.

Penentuan sampel dilakukan secara purposive sampling. Perusahaan yang terpilih menjadi sampel telah memenuhi kriteria sebagai berikut. 1) perusahaan yang melakukan pergantian CEO di BEI periode 2008-2018,2) perusahaan yang melakukan pergantian CEO secara tidak rutin periode 2008-2018, 3) perusahaan yang melakukan pergantian CEO tidak dengan alasan meninggal, pensiun, masa jabatan habis, 4) perusahaan yang melakukan pergantian CEO tanpa pengumuman lain (confounding effect).

Tabel 1.

\section{Prosedur Penentuan Sampel}

\begin{tabular}{clc}
\hline No & \multicolumn{1}{c}{ Kriteria } & Jumlah \\
\hline 1 & Pengumuman Pergantian CEO periode 2008-2018 & 160 \\
2 & Pengumuman Pergantian rutin dengan alasan 1) & $(69)$ \\
& $\begin{array}{l}\text { Meninggal, 2) Pensiun, dan 3) Masa Jabatan Habis } \\
3\end{array}$ & $\begin{array}{l}\text { Pengumuman Pergantian CEO dengan confounding } \\
\text { effect }\end{array}$ \\
\hline & Jumlah Sampel & (12) \\
\hline Sumber: & Data & 79 \\
\hline
\end{tabular}

Sumber: Data diolah, 2018 
ISSN: 2302-8556

E-Jurnal Akuntansi Universitas Udayana

Vol.25.3.Desember (2018): 2427- 2455

Berdasarkan prosedur penentuan sampel pada tabel, sampel pada penelitian ini sebanyak 79 sampel perusahaan yang akan diteliti. Sampel yang digunakan pada penelitian ini berjumlah 79 sampel dengan pergantian tidak rutin tanpa pengumuman lain (confounding effect).

Metode pengumpulan data yang digunakan dalam penelitian ini adalah metode observasi non partisipan. Data kuantitatif adalah metode penelitian yang berlandaskan filsafat positivism, digunakan untuk meneliti pada populasi atau sampel tertentu, pengumpulan data menggunakan instrument penelitian, analisis data bersifat kuantitatif/statistik (Sugiyono, 2017:8). Data yang diamati selama periode 2008-2018. Data yang dibutuhkan dalam penelitian ini, yaitu; 1) tanggal pengumuman pergantian chief executive officer (CEO); 2) daftar harga saham dan harga adjusted closing price untuk menghitung return sesungguhnya dan return ekspektasian periode jendela penelitia; 3) nama-nama perusahaan yang mengumumkan pergantian CEO yang terdaftar di Bursa Efek Indonesia.

Sumber data sekunder dapat diperoleh dari database Bursa Efek Indonesia di download melalui situs www.idx.co.id dan data harga saham menggunakan adjusted closing price per emiten melalui situs finance.yahoo.com. Alasannya untuk mencerminkan harga penutupan yang telah disesuaikan dengan perubahan nilai saham yang disebabkan oleh penawaran baru perusahaan. Pengumuman Pergantian CEO, literatur serta media internet lain yang mendukung penelitian ini.

Teknik analisis data yang digunakan untuk membahas permasalahan dalam penelitian ini adalah metode pengujian one sample t-test. Setelah variabel dihitung, maka analisis dapat dilakukan. Data yang telah terkumpul kemudian 
dilakukan pengujian uji one sample t-test untuk mengukur abnormal return pengumuman pergantian chief executive officer (CEO).

Studi peristiwa merupakan studi yang mempelajari reaksi pasar terhadap suatu peristiwa (event) yang informasinya dipublikasikan sebagai suatu pengumuman. Periode penelitian ini yang digunakan dalam studi peristiwa ini adalah selama lima hari, dua hari perdagangan saham sebelum terjadinya peristiwa ( $\mathrm{t}-2$ ) hinggan dua hari perdagangan saham setelah terjadinya peristiwa $(\mathrm{t}+2)$. Tanggal pergantian CEO yaitu $\mathrm{t}-0$ dipilih pada tanggal RUPS/RUPSLB perusahaan yang melakukan pergantian CEO. Klasifikasi yang tidak dimasukan kedalam penelitian, yaitu meninggal, pensiun, dan masa jabatan habis. Alasan pengambilan periode $\mathrm{t}-2$ dan $\mathrm{t}+2$ adalah bertujuan menghindari adanya corporate action diluar peristiwa pergantian chief executive officer (CEO) seperti peristiwa pengumuman pembagian dividen tunai, dividen saham, right issue, warran/saham bonus, merger, akuisisi, stock split dan reverse stock. Peristiwa pergantian chief executive officer (CEO) dipublikasikan oleh media sesuai dengan pengumuman yang telah diterima dari perusahaan. Sehingga, hari peristiwa setiap perusahaan berbeda.

Uji-t signifikansi dalam penelitian ini diuji menggunakan uji one sample ttest selama 5 hari periode peristiwa. Tujuan pengujian dengan one sample t-test adalah untuk memperlihatkan apakah pada peristiwa terdapat abnormal return yang signifikan disekitar pengumuman pergantian CEO. Tingkat signifikansi yang dimaksud yakni abnormal return secara statistik signifikan tidak sama dengan nol (positif untuk good news dan negatif untuk bad news) (Tandelilin, 2010). 
Pengambilan keputusan menggunakan tingkat kepercayaan $95 \%$ atau $\alpha=5 \%$ persen dengan kriteria pengujian apabila nilai probabilitas $>0,05$ maka $\mathrm{H}_{0}$ diterima dan $\mathrm{H}_{1}$ ditolak sedangkan, apabila nilai probabilitas $\leq 0,05$ maka $\mathrm{H}_{0}$ ditolak dan $\mathrm{H}_{1}$ diterima.

\section{HASIL DAN PEMBAHASAN}

Berdasarkan hasil pengamatan 79 sampel perusahaan di Bursa Efek Indonesia yang melakukan pergantian CEO. Pengujian menghapus unsur pengumuman lain (confounding effect) agar sampel tidak dipengaruhi oleh faktor perancu. Deskripsi variabel penelitian menyampaikan informasi mengenai karakteristik variabelvariabel penelitian yang terdiri atas jumlah pengamatan, nilai minimum, nilai maksimum, nilai rata-rata, dan nilai standar deviasi. Tabel memperlihatkan hasil analisis statistik deskriptif.

Tabel 2.

Statistik Deskriptif

\begin{tabular}{lccccc}
\hline & N & Minimum & Maximum & Mean & $\begin{array}{c}\text { Std. } \\
\text { Deviation }\end{array}$ \\
\hline Return_Realisasian & 79 & $-0,3305$ & 0,2559 & 0,0073 & 0,0721 \\
Return_Ekspetasi & 79 & $-0,0732$ & 0,0762 & 0,0019 & 0,0245 \\
CAR & 79 & $-0,3217$ & 0,2414 & 0,0059 & 0,0689 \\
Valid N (listwise) & 79 & & & & \\
\hline
\end{tabular}

Sumber: Data diolah, 2018

Berdasarkan tabel statistik deskriptif return realisasian yang dihitung menggunakan return total dengan jumlah sebanyak 79 perusahaan selama selama lima hari pengamatan memiliki nilai minimum sebesar $-0,3305$ dan nilai maksimum sebesar 0,2559. Rata-rata return realisasi sebesar 0,0073 dengan standar deviasi 0,0721 yang berarti selama lima hari pengamatan investor mendapat return realisasian sebesar 0, 0073. 
Return ekspetasi dihitung menggunakan harga index IHSG sebanyak 79 perusahaan, menghasilkan return ekspektasi minimum sebesar $-0,0732$ dan nilai maksimum sebesar 0,0762. Rata-rata return ekspektasi sebesar 0,0019 dengan standar deviasi 0,0245 yang berarti selama lima hari pengataman investor memiliki return ekspetasian dengan rata-rata sebesar 0,0019 .

Cumulative abnormal return (CAR) secara keseluruhan dengan 79 perusahaan yang digunakan selama lima hari pengamatan. Nilai CAR yang diperoleh sebesar -0,3217. Nilai minimum dimiliki oleh PT Paramita Bangun Sarana Tbk pada sektor konstruksi bangunan. Nilai maksimum CAR sebesar 0,2414 dimiliki oleh PT Trada Alam Mineral Tbk pada sektor pertambangan batu bara. Nilai rata-rata CAR sebesar 0,0059 dengan standar deviasi sebesar 0,0689.

Berdasarkan hasil uji one sample t-test dilakukan untuk menguji hipotesis 1 yaitu pengumuman pergantian CEO direaksi positif oleh pasar modal di Indonesia. Menggunakan variabel cumulative abnormal return (CAR). Hasil pengujian disajikan pada Tabel 3.

Tabel 3.

Uji One-Sample t-Test

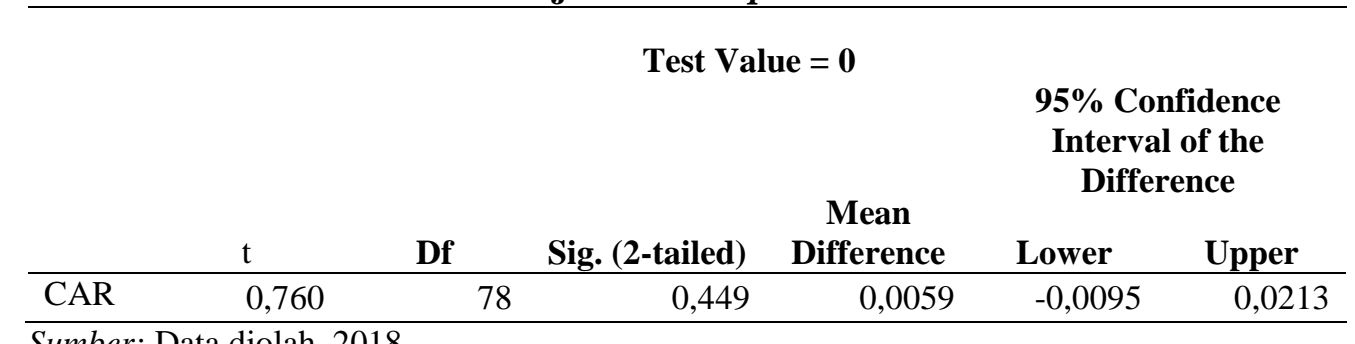

Sumber: Data diolah, 2018

Berdasarkan hasil uji one sampel t-test pada Tabel 3. menunjukkan hasil cumulative abnormal return (CAR) selama periode pengamatan memperoleh nilai 
ISSN: 2302-8556

E-Jurnal Akuntansi Universitas Udayana

Vol.25.3.Desember (2018): 2427- 2455

t sebesar 0,760 dengan nilai probabilitas sebesar $0,449>\alpha(0,05)$, yang berarti bahwa tidak terdapat reaksi pasar atas pengumuman pergantian CEO.

Pengumuman pegantian CEO membahas mengenai pergantian yang dilakukan oleh perusahaan untuk meningkatkan performa kinerja perusahaan. Penelitian ini menggunakan metode event study yang diasumsikan bahwa pasar berbentuk setengah kuat, sehingga harga-harga sekuritas yang terdaftar di dalamnya diharapkan mencerminkan secara penuh informasi yang dipublikasikan (Hartono, 2016:643). Informasi yang dipublikasikan tersebut dapat menjadi sinyal bagi para investor untuk mengambil keputusan dalam berinvestasi. Apabila informasi yang dipublikasikan mengandung sinyal negatif, maka akan timbul reaksi negatif dari investor yang ditandai dengan diperolehnya abnormal return negatif. Sementara itu, apabila informasi yang dipublikasikan mengandung sinyal positif, maka akan timbul reaksi positif dari investor yang ditandai dengan diperolehnya abnormal return positif di sekitar peristiwa tersebut. Penelitian ini berfokus pada reaksi pasar terhadap pergantian CEO dengan dugaan bahwa terdapat abnormal return positif pada saham perusahaan-perusahaan yang di sekitar pengumuman pergantian CEO.

Berdasarkan hasil uji hipotesis 1 dengan nilai probabilitas $0,449>\alpha(0,05)$ yang berarti bahwa tidak ada reaksi pasar terhadap pengumuman pergantian CEO di Bursa Efek Indonesia. Artinya bahwa selama lima hari dilakukannya pengamatan terhadap pengumuman pergantian CEO tanpa pengumuman lain (confounding effect) yang menunjukkan tidak terdapat kandungan informasi dan tidak mempengaruhi keputusan investor dalam berinvestasi. 
Pergantian CEO merupakan salah satu fenomena internal perusahaan yang dilakukan secara rutin dan tidak rutin. Pergantian CEO adalah sinyal dari perusahaan bahwa mereka akan membuat perubahan dalam manajemen perusahaan (Setiawan, 2008) Hasil dari penelitian ini selajan dengan penelitian Warner et al., (1988) menyimpulkan peristiwa pergantian manajemen puncak terhadap reaksi pasar yang dilihat dari harga pasar sangat kecil. Penelitian dilakukan dengan sampel 269 peusahaan yang listing di NYSE dan AMEX pada periode 1963-1978. Penelitian ini menunjukkan tidak ada reaksi pada saat pengumuman tersebut. Hasil penelitian juga selajan dengan penelitian Setiawan (2008) menyatakan perubahan CEO non-rutin adalah sinyal campuran untuk investor. Mereka tidak yakin tentang cara CEO baru mengelola perusahaan. Hal ini tercermin dengan hasil yang beragam pada periode jendela, baik untuk perubahan non-rutin di dalam maupun di luar non-rutin. Hasil penelitian menunjukkan pergantian non-rutin menunjukkan pasar tidak bereaksi terhadap informasi pergantian CEO.

\section{SIMPULAN}

Simpulan dari hasil penelitian ini adalah pengumuman pergantian CEO menunjukkan tidak terdapat kandungan informasi dan tidak mempengaruhi keputusan investor dalam berinvestasi. Mengetahui bahwa pengumuman pergantian CEO tidak berpengaruh signifikan terhadap abnormal return. Teridentifikasikan bahwa pengumuman pergantian CEO tidak dapat menciptakan kenaikan harga saham yang signifikan, maka investor tidak perlu memperhatikan tanggal pergantian CEO. Penelitian selanjutnya sebaiknya meneliti fenomena 
saham lainnya yang dapat mempengaruhi di bidang ekonomi. Pergantian untuk penelitian selanjutnya dapat menspesifikasi dari pengganti CEO dari dalam perusahaan (inside) dan dari luar perusahaan (outside) yang melakukan pergantian CEO secara terpaksa dengan tidak memasukan kriteria pergantian yaitu masa jabatan habis, meninggal, dan pensiun. Penelitian selanjutnya dapat membandingkan antara kinerja perusahaan positif dengan kinerja perusahaan negatif dalam meneliti reaksi pasar terhadap pengumuman pergantian CEO.

\section{REFERENSI}

Alwi, Z., Iskandar. (2003). Pasar Modal: Teori dan Aplikasi. 1st ed. Jakarta: Nasindo Internusa.

Bahtera, N. T. (2017). The Indonesian Journal of Applied Business, The Indonesian Journal of Applied Business, 1(1), 14-29.

Badriyah, Lailatul. (2015). Pengaruh Pergantian Chief Executive Officer (CEO) dan Corporate Governance Terhadap Kinerja Perusahaan yang Terdaftar di Indeks Saham Syariah Indonesia (ISSI) Periode 2012-2014. Skripsi. Fakultas Syari'ah dan Hukum Universitas Islam Negeri Sunan Kalijaga Yogyakarta.

Beaver, W. (1968). The Information Content of Annual Earnings Announcement. Empirical Research in Accounting. Supplement to Journal of Accounting Research, 6, 67-92.

Clayton, Mathew J., Jay C Hartzell, \& Joshua Rosenberg. (2003). The Impact of CEO Turnover on Equity Volatility. Federal Reserve Bank of New York Staff Reports No. 166.

Dahya, Jay., \& John J. Mc Connel. (2002). Outside Directors and Corporate Board Decisions. (On-line) Available http://ssrn.com

Denis, David J., \& Dianne K. Denis. (1995). Performance Changes Following Top Management Dismissals. The Journal of Finance. 1(4).

Dherment-Ferere, I., and Renneboog, L. (2000). Share Price Reaction to CEO Resignations Large Shareholder Monitoring in Listed French Companies. Center for Economic Research, No. 2000-70. Available http://www.ssrn.com. 
Dewi, Gusti Ayu Surya Rosita, Wirama, Dewa Gede, \& Rasmini, Ni Ketut. (2017). Reaksi Pasar Atas Pengumuman Paket Kebijakan Ekonomi X Tentang DaftarNegatif Investasi. Jurnal Ilmiah Akuntansi dan Bisnis. 12(2). 104-114.

Hartono, J. (2015). Teori Portofolio dan Analisis Investasi. 10th ed. Yogyakarta: BPFE.

Hartono, J. (2016). Teori Portofolio dan Analisis Investasi. BPFE Yogyakarta, 11th ed, Yogyakarta.

Jayanthi, Putu Yuvita \& Putra, I Wayan. (2013). Manajemen Laba dan Respon Pasar di Sekitar Pergantian CEO. E-Jurnal Akuntansi, 5(1), 147-162.

Jauch Lawrence R. \& Glueck William F., (1989), 'Manajemen Dan Strategis Kebijakan Perusahaan', Jakarta : Erlangga.

Kang, Joo-Koo, \& Shivdasani, A. (1996). Does The Japanese Governance System Enhance Shareholder Wealth? Evidence from The Stock-Price Effect of Top Mangement Tornover. The Review of Financial Studies Winter. 9(4), 10611095.

Kurniasari, Ninik, Nugraheni, B. \& Linggar Yekti. (2003), "Reaksi Pasar Terhadap Right Issue Pada Saat Ex Date". Jurnal Ekonomi dan Bisnis (Dian Ekonomi), 9(2).

Nainggolan, L. W. (2009). Reaksi Pasar Terhadap Pengumuman Pergantian Chief Executive Officer (CEO) Diukur dengan Abnormal Volume, Skripsi, Fakultas Ekonomi Universitas Sebelas Maret Surakarta.

Neumann, Robert., \& Torben Voetmann. (1999). CEO Turnovers and Corporate Governance: Evidence from the Copenhagen Stock Exchange. The $26^{\text {th }}$ Annual Meeting of The European Finance Association August 25-28.

Primasari, A. A. Paramita, \& Sukartha, I Made. (2016). Reaksi Pasar Terhadap Male-To-Female Chief Executive Officer Turnover, E-Jurnal Akuntansi Universitas Udayana, 16(2), 978-1006.

Pourciau, Susan. (1993). Earnings Management and Nonroutine Executive Change, Journal of Accounting and Economics. 16. 317-336.

Sugiyono. (2017). Metode Penelitian Kuantitatif dan Kualitatif. Bandung: Alfabeta. 
Sedianingtias, Rahayu, Eka. (2010). Analisis Dampak Pengumuman Right Issue Terhadap Return Dan Resiko Saham Berdasarkan Tujuan Penggunaan Dana. Skripsi. Universitas Sebelas Maret. Surakarta.

Stewart D. Friedman \& Harbir Singh. (1989). CEO Succession and Stockholder Reaction: The Influence of Organizational Context and Event Content. The Academy of Management Journal, 32(4), 718-744.

Setiawan, Doddy. (2008). An Analysis Of Market Reaction To CEO Turnover Announcement: The Case In Indonesia. Business \& Economics Research Journal, 7(2), 119-128.

Tandelilin, E. (2010). Portofolio dan Investasi. 1st ed. Yogyakarta: Kanisius.

Undang-Undang Republik Indonesia Nomor 40 Tahun 2007 tentang Perseroan Terbatas.

Warner, J. B., Watts, R.L., and Wruck, K.H. (1988). Stock Prices and Top Management Changes. Journal of Financial Economics, 20, 461-492.

Yahoo finance. (2018). https://finance.yahoo.com/ Diakses 10 Mei 2018

Yuliana, Chandra. (2011). Pengaruh Leverage, Pergantian CEO dan Motivasi Pajak terhadap Manajemen Laba. JRAK, 7(1): 19-29.

Merdeka.com. (2018). https://www.merdeka.com/uang/proyek-waskita-karyakembali-tertimpa-kecelakaan-kerja-bagaimana-dampak-ke-sahamnya.html (diakses pada tanggal 15 Mei 2018) 